\title{
A Dramatisation of Research Outcomes: A Verbatim Drama Based on the Lived Experience of Women Casual Academics
}

\author{
Gail Crimmins ${ }^{1}$ \\ University of the Sunshine Coast \\ Sunshine Coast, Queensland \\ GCrimmin@usc.edu.au
}

\begin{abstract}
Within this article I offer a brief rationale for de-disciplining and re-disciplining research communication, present a drama script using the words - verbatim - of six women casual academics from across three Australian universities, and offer a succinct rationale for employing artistic forms of communication more generally, and drama more particularly, for re-presenting lived experience. The article predominantly focuses on the stories of women causal academics in Australian universities. It is their voices that are privileged and centralised. Women casual academics make up the majority of academics in Australia, yet they are currently "un-voiced." This article therefore creates some space for the voices of women causal academics to be heard and known in a form that is congruent to their lived experience.
\end{abstract}

Keywords: casual academics, narrative research, traditional academic discourse, verbatim drama, voice.

\footnotetext{
${ }^{1}$ Biographical statement: Gail is an experienced actor and director whose research explores and illuminates the lived experience of women. She has researched the experience of women casual academics, mothers with rheumatoid arthritis, and women survivors of domestic and family violence. Gail employs participatory research methods and re-presents the research in a variety of forms including theatre, film and written prose. She works with the premise that you need "new bottles for new wine;" that is, if you have something new to say then you need new and congruent forms through which to express the content.
} 
The following verbatim drama script, created as part of a narrative inquiry into the lived experience of women casual academics, was presented in full within my $\mathrm{PhD}$ dissertation, and a performance of the drama was published as six discrete videos, which you will find here:

\section{https://ualberta.aviaryplatform.com/r/s756d5qb0j}

I chose to dramatize research outcomes because of drama's ability "to give voice to people who might otherwise go voiceless, or to give listening ears to voices that often go unheard" (Wake, 2010, p. 3). Yet, as a form through which to disseminate research outcomes drama is still a relatively new phenomenon, and one that runs counter to traditional academic discourse. Indeed, in traditional scholarship research findings are usually presented as a selection of analysed research data within tables, diagrams and graphs, and research outcomes generally comprise a selection of case study responses, ethnographic field notes or extracts from interviews (Bloomberg \& Volpe, 2008; Evans, Gruba, \& Zobel, 2011). Both forms of research data are usually anchored by the researcher's explanation of her/his choice of data selection, analytical process undertaken, and what s/he has determined the data to represent (Evans, et al., 2011). Correspondingly, typical research accounts present a narrow, linear, and monologic narrative, which leave little room for differing interpretations or perspectives. Additionally, the researcher's interpretation of the data is traditionally presented in a third person "objective" discourse, which tends to suggest that the researcher holds an objective position within the research communication. Consequently, the partial and interested nature of research reportage is often made invisible to the reader, disguised by the seemingly disinterested guise of the third person narrative (Richardson, 1997). Therefore, more transparent and honest representations of research make explicit the partiality of the data communication, and the personally constructed and idiosyncratic nature of academic scholarship. Drama as a form through which to re-present research data is thus a more transparent form of research communication than traditional discourse, as it looks, feels and sounds like a personally constructed and nuanced interpretation of research findings.

Furthermore, I feel that research that is aimed at re-presenting lived experience should be communicated in a form that is congruent with how lives are lived so that the content (the lived experience) is not drowned out, upstaged or uprooted by the form (of analytical discourse). So if lives are understood to be experienced and expressed through narrative (Bruner, 1986, 1990, 1996; Hardy, 1968); are messy (Etherington, 2004); understood in images and sensations with their own inherent "logic of sense" (Deleuze, 1990); and lived with full embodiment (Merleau-Ponty, 1962), research communication that expresses lived experience ought to accommodate and express the messiness, imagistic and fully embodied narrative nature of experience. Drama is one such form of communication that can achieve this.

In addition, drama can also express and evoke how lives are lived and understood. Gould (1996) and Etherington (2004) observed that life cannot be 
explained or encapsulated fully in traditional written communication, and Hendry (2010) suggested that experience requires interpretation not explanation, and that interpretation requires communication methods that are distinct from argumentative discourse. That is, traditional written forms of academic text that seek to explain experience fail to fully express or illuminate it. As Dewey (1934) explained, art "does something different from leading to an experience. It constitutes one" (cited in de Mello, 2007, p. 207). This is supported by Barone (2000), who argued that art creates an opportunity for experience to be known and engaged in vicariously. I thus chose to re-present the lived experience of women casual academics in a drama because of its ability to make explicit the nuanced and subjective nature of my retelling of the women's experiences; for its capacity to express the messiness and fully embodied nature of narrated experience; and for its adeptness in expressing lives and creating vicarious and congruent experience for audiences/readers. I therefore identified drama as a form through which I could re-present the story of women casual academics' lived experiences.

Casual academics, also known as adjunct, contingent or sessional academics, constitute 61 per cent of Australian academics and most casual academics are women (May, Strachan, Broadbent, \& Peetz, 2011), yet very little is known about these women's experiences (Coates, Dobson, Edwards, Friedman, Goedegebuure, \& Meek, 2009). Hence, I engaged in a narrative inquiry with six women casual academics from across three different universities in South East Queensland to elicit their stories of working as adjunct or sessional staff. I then applied drama to congruently and transparently express the voices of the "yet to be voiced" (Arnot \& Reay, 2007) lives of the academics (such as these women) who undertake most of the teaching in Australian universities, and who serve to shape the minds of the current and future thinkers of the world.

\section{A Research Narrative in the Form of a Drama: A Verbatim Drama Based on the Lived Experience of Woman Casual Academics}

Characters:

Anna: woman in her early 30 s, a married sessional academic with a $\mathrm{PhD}$

Lyn: woman in her late 40s, a married sessional academic with one child

Rainee: woman in her mid-50s, a married sessional academic

Sharon: woman in her early 50s, a single parent with two children

Tasha: a Greek figure, a commentator on the action 
Context: The current context is a university setting in 2014. Dress code, images and iconography reflect this time frame. The dress codes and iconography should locate the action in the mid-2010s to anchor the narrative historically.

\section{Prologue}

Set on a bare stage.

Gail: $\quad$ The research I would like to share with you today is in an arts-informed narrative inquiry into the lived experience of women casual academics.

Arts-informed research is an approach to qualitative research in the social sciences that is informed by but not based in the arts. Its main aim is to enhance our understanding of the human condition through alternative (to conventional) representational forms of inquiry. In practice, arts-informed research merges the methodical and rigorous processes of social science inquiry with the artistic and imaginative form and qualities of the arts.

The particular form of arts-informed inquiry that you'll see today is a verbatim drama, where the text presented employs the words and communication of research participants - verbatim. The focus of the drama is the lived experience of women casual academics.

In order to create the drama I engaged with six women casual academics (also known as sessional staff) from across three universities in Australia and asked them an open-ended question: When and in what circumstance did you become a casual academic?

"When and in what circumstance did you become a casual academic?" is projected on the screen at the back of the stage

\section{Scene 1: When and in what circumstance did you become a casual academic?}

Sharon: I'm a single mum, I came here because I fell in love with an Australian man and he wound up basically abusing me - it took me years to get out of the relationship. He strangled me, I almost died and I'm the least likely candidate for that. So I wound up learning to teach at uni to sustain my life to make me the bread-winner, as a single mother...

I'm really proud of what l've done, in a foreign country. It was just so synchronistic that I was doing my Masters when they needed people to teach an undergraduate course that was linked to my study. It had me 
written all over it so when Steve McKeith came to town to write the course and get it organized I begged with him to tutor into it.

Anna: $\quad$ In 2000 I started demonstrating - and tutoring about 2002, 2003. Then in doing my PhD I picked up more tutoring. I love teaching, I love working with the students. It's always really rewarding to see them get what we're teaching, get the concepts we're trying to get across, to actually see them understand and know what to do with it is really, really rewarding. I'd always wanted to be an academic. But... this year may be my last semester, not necessarily by choice... but as a response to finances. You've got to follow the money.

Rainee: I started in 2002. I was working in a studio as a graphic designer and there was an industry association being formed. Some people from the uni came to where I was working and asked if I was interested in joining it 'cos I was well established in the industry.

So I was interested, yeah, I started coming to these meetings and getting to know - because the meetings took place at the uni as well and while here I met a program director and he mentioned that he needed somebody for one of the courses he was developing. I thought yeah, I can do that 'cos almost 20 years ago l'd taught a similar course at TAFE. So it was a natural... I was really happy to get back into teaching again.

Lyn: $\quad$ Twenty years ago I was working full time as a Senior Public Servant and my daughter just got diagnosed with a brain tumour (pause). So, I just kept working, but after a year of so it just wasn't possible and I just wasn't emotionally in a... in a space where I could work full time. My daughter was nearly four at the time. So... most of that time was spent at the hospital and... and life just gets busy with appointments. And then I knew a friend who worked at the uni and she said, "Well, why don't you work as a tutor? We'd love to have somebody like you as a tutor." So I did that and I quite enjoyed it.

Sharon: $\quad$ And I wasn't at the meeting but Karen told me about a meeting she was at where one of the senior people in the department said, "Oh, you know casual tutors they only do it 'cos they can't get a job anywhere else."

Anna: and I'm sure that that's a feeling amongst some, not others, but some would ask...

Rainee: "You know, why would you be a casual tutor?" 
Lyn: $\quad$...yet there's this wealth of experience.

All: $\quad$ We've done jobs that most academics have only read about and will never do in their whole lives.

Lyn: I was a founding member of the criminal justice commission...

I used to set up new public building designs and managed huge million dollar projects and here's some you know wanky little associate professor, 'specially the males, treating me like some old woman who they have to sort of "suffer".

Sharon: I was an established artist and art director; I lived a full and creative life I...

Rainee: I was a full time graphic designer with a large client base

Anna: $\quad$ and now I have my doctorate and I always wanted to be academic

Rainee: But I took on sessional teaching because I absolutely love teaching. I started off teaching one day a week and the rest of the time, the other four days a week I was working in the industry. It's just that I got, I got really - I really loved the teaching and there were other courses that I found that I could teach, so I wanted to apply for them.

My kids had left home then and I didn't have - I would not have done that, taken the jump until my kids had left because of the insecurity, that's what really worried me because I had a very secure job and then to give that up.

Lyn: $\quad$ So I started off with one or two core subjects, but now I teach $2^{\text {nd }}$ year, $3^{\text {rd }}$ year and at Masters Level and I mark Masters level papers and I do it well.

Sharon: And I found that I absolutely loved the teaching. I'm an educator and feel strongly about the subject matter. I just was awarded an excellence in teaching award so yeah, I'm very proud of it all. I've been a sessional for 13 years and I get as many tutorials as I can and I do them well and I get enough work to create a living as a single mother.

Lyn: $\quad$ And I grew to love teaching.

Anna: I so love the teaching element of it - the interaction with the students

Lyn: the interaction, taking a student, especially I think in a first year course because you're working so much with beginners at the learning and social level of university, working with people that you can see 
before your eyes transformed from scared little bunnies to people who are confident to go on - to go on...

Sharon: $\quad$ to help the students find just their place, their identity and own it is really exciting.

Anna: It's not the processes of the teaching that's the draw, for me. It's the experience of watching students find something special in whatever it is you're teaching them.

Rainee: It's an honour being in front of the students. I bring life experience to my teaching

Lyn: $\quad$ And even though sometimes you're delivering somebody else's material you're doing it through your own framework and with a creativity... to make it more interesting... and with the language and with the images that you use and the examples, they're you. They're an expression of the way that you understand and the way that you see things.

Lyn: It's a privilege. It's amazing, l've been doing it for 20 years and I still get excited before every class

All: $\quad$ Every class (Lyn)

Every bunch of students (Lyn and Anna)

Every time (Lyn, Anna and Sharon)

That is the real joy of it. (Lyn, Anna, Sharon and Rainee)

All: It's rewarding, you're engaged, you're excited, and you just really like the teaching.

Sharon: $\quad$ Oh, that shot in the arm. That rush, it's addictive. It's that engaging with the students, it's that moment when they get something or I don't know, it's fun to be the star of the show, being up front. I don't know, it's just really...So that's when I took the leap and I just quit my other job.

Lyn: $\quad$ It's for the students; it's not about me.

Anna: I like being at the uni. I like that student energy. I really like young people. There's that age group, that early 20 s. They are just - it is the most profound time of your life. Everything is just so interesting. So I really like being in that space. 
Rainee: $\quad$ Most of the time it is the best job in world - and we have this opportunity to add quality to people's lives.

Lyn: $\quad$ And then one of the senior people in the department says, "Oh, you know casual tutors they only do it 'cos they can't get a job anywhere else."

\section{Scene 2: And then there's this long wait in-between semesters}

Rainee: I still enjoy the teaching, but there's this contradiction.

Anna: $\quad$ There's this drown or drought, the busyness and life-ness of semester and then there's this long wait in between semesters.

Sharon: I found that the worst thing about it - especially when I started doing sessional work as my main gig - was the insecurity and the gap between semesters.

Lyn: I find that wait really awful and that uncertainty, like you just don't know, you can't plan. Luckily I had already bought a house so I didn't have to worry about... because you can't get a loan... all of those financial things are a problem.

Anna: I don't know what's happening; I don't know what's going to happen. I don't know what's going to happen... and it's almost three months or two and a half months.

Tasha: $\quad$ Sung to the tune Skinny Love (Vernon, 2007²)

Come on skinny love just last the year,

Pour a little salt we were never here,

My mymy, my mymy, my-my my-my...

Staring at the sink of blood and crushed veneer.

Tell my love to wreck it all,

Cut out all the ropes and let me fall,

My mymy, my mymy, my-my my-my...

Right in the moment this order's tall.

Tasha and Cast:

And I told you to be patient,

And I need to be patient

2 Permission to reproduce the lyrics granted by Hal Leonard Australia Pty Ltd. 
And I told you to be fine,

And I told you to be balanced,

And I told you to be kind,

And in the morning l'll be with you,

But it will be a different kind,

Cos I'll be holding all the tickets, tickets

And you'll be owning all the fines.
And I need to be fine

And I need to be balanced

And I need to be kind

In the morning l'll be waiting

But it will be a different kind

Cos you'll be holding the

And I'll be owning all the fines

Rainee: $\quad$ You start, well I start to get a bit not actually stressed but I suppose it is stressed, but it's something I suppose over the years I've learned to control. Because you let the stress overtake you and you can't function properly. But it's just always there in the back of your mind around where's the money coming from after this?

Lyn: $\quad$ You wait.

All: $\quad$ Life on hold.

Anna: The semester breaks, the anxiousness and frustrations... so long.

Lyn: $\quad$ But worrying about the future and certainty... using brain cells to worry about the future is so unproductive. It's unfair. Every time it enters my head l've had to reprogram my brain and say that university is lucky to have me. That's how I cope with the "not knowing" part of the job those huge feelings... of uncertainty.

Sharon: I need to positive self-talk because since I suffered the domestic violence, I know I now have what is known as a victim mentality. I don't know if you know anything about the cycle of abuse in marriage but after it happens to you, you become programmed to think that it your fault that you.... get hit, that you get strangled, that you get something thrown at you. You believe you deserve it because you made it happen, so because it happened to me, I sometimes find similar thoughts going through my mind regarding sessional work... It may sound something like this: Well, l'm not really as good as the others; well it's my own fault because I didn't get that Master's degree right out of university. Or I copped out and had an arts degree instead of something that I could really use in society. So that victim mentality rears its ugly head once semester's over... And, you know, you've worked so hard and you're exhausted, so negative thoughts can settle in.

Lyn: So you'd have more security if you worked in McDonalds. 
Tasha: Who will love you?

Who will fight?

And who will fall far behind?

\section{Scene 3: But the biggest problem with casual work is financial}

Sharon: $\quad$ So there's this beauty and benefit in being a sessional but it comes with the uncertainty and, in my case, a knock to my self-esteem. But the biggest problem with casual work is financial.

Lyn: $\quad$ That's the thing... it's always... it's just always there at the forefront of your mind; always thinking about where's the money coming from? The not knowing affects your whole life. My life's on hold... and yet l've been doing this for about 20 years now.

Anna: $\quad$ When the car breaks down, I have to save for months before I can get it fixed. I catch buses and hang around campus for hours waiting for a bus home

Lyn: $\quad$ My dishwasher broke on my 50th birthday and I'm now 52 and....

Sharon: If something breaks, you don't replace it.

Rainee: $\quad$ We're now in a position in our fifties where we don't have enough, we can't see how we can have enough for retirement - but we've got to. My husband's got to work really, really hard and channel as much as possible into trying to recoup our losses. So while he now has a good income... there's only a pretty modest percentage of it that can be used for living, now - living now.

Anna: $\quad$ and even though we may be working in a professional capacity and we're working long hours, actually the average salary is really low.

Lyn: $\quad$ I haven't had to pay tax for almost 20 years... Since working as a casual academic l've never earned enough to actually pay tax. And what's the tax threshold?... about $\$ 16,000$ or $\$ 18,000$, but that's only in the last 12 months.

Anna: l've never earned more than $\$ 10,000$ a year as a sessional, never.

Rainee: I go to an accountant at tax time because we are desperately trying to find ways to save on tax and the accountant would say, "How do you eat?" It was a simple equation; we kept going to the bank and... extending our mortgage. 
Sharon: I have a personal superannuation policy that at the moment would pay out $\$ 2500$ and I'm 54. So l've got no hope unless I get a job and work at least 15 years fulltime l'm not going to have anything other than enough super to maybe have a credit card, certainly not to be able to say that I could secure myself for retirement. And seeing emails that come around about Uni Super and stuff coming on campus to give you advice, and I think there's no point me going until I have a job.

Anna: What can they advise me to do when all I can say is 'well, in semester one I have no work'? 'I won't have an income as far as I know in semester one, unless someone asks me to tutor which l'll find out probably at the end of January'. So I can't plan holidays, I can't plan anything.

Rainee: And that's where the guilt starts to come in where I think that's really unfair on my family and perhaps I should be looking for work outside of academia, forget about the teaching, forget about the knowledge and skills from the PhD because that's useless out in the community, nobody wants to know about that. Again that's only useful in academia.

Sharon: $\quad$ And l'm always desperate for my next pay cheque, to add that to those huge feelings of uncertainty... So what happens is that I take on an enormous amount of teaching hours and it's usually anywhere... the least I teach is like 16 hours face to face... which if it was just teaching is a piece of cake, l'd love it, but it's not just teaching, it's the prepping, the marking, emailing...

Sharon: $\quad$ Yes, you've got to strategize. For me it's around week 10 or 11 of a semester when you get very cognisant that there's only three weeks left. I may get a couple of extra weeks' pay if I put my timesheets in at the right time - so you hold off putting in timesheets for marking and the extra OA (other hours) hours and all that stuff... to stretch your income between semesters.

Rainee: I always do my taxes at the very end because you know how you get a big tax return, so that carries you through the summer, well most of it anyway, so that's my strategy. It's like a forced savings plan.

Rainee: $\quad$ The thing I do like strategically is I try to teach as many courses as possible because that first tutorial is worth more money. So if I can get a few more first tutorials then I get more money, but what happens is that then I have to prepare and what l've done over the years too is I've taught, like l've tried to take on one new course every semester. 
Lyn: $\quad$ Well, usually I try to work it out so that I'm at uni four days a week. So that way I have at least one marking day. Sometimes it works out that I'm there three days a week. Last semester, first semester, I had three days a week, but two of those days, one was a 12-hour day and one was a 13-hour day. So it was - and you have those breaks in between, but you are there the whole - but it worked out because then I had days on either side, Monday and Friday to do all the prep and all of that stuff and I could do it in a more calm way.

Rainee: But then there's the marking. A lot of marking comes in at the same time and there are these periods of intensity then...

Sharon: week five's very intensive, that's a really intense time. And around week eight and nine that's when they all come in again. So during the semester I work seven days a week always, like the entire semester there's never - I schedule myself so that I work early in the morning.

Sharon: $\quad$ So I will get up anywhere from 3:30 and then I will work for a few hours and then take a break for breakfast. So I have a good work schedule... it's almost like having two days in one.

Lyn: $\quad$ And I work weekends as well - Oh yeah, you have to. You don't ever take a day off during the semester.

Rainee: $\quad$ And even though l'm putting in all these hours there's a lot of guilt around the fact that I don't contribute enough at home... financially

Sharon: this might sound silly - I almost see what I do as a form of community service and all of my adult life, until I was in the second year of my undergraduate degree, I would have done 10 to 15 hours a week of community service of one kind or I had to stop that if I was going to actually finish my degree. Now out the other end and being the teacher, I feel like l've regained that commitment that I've made as teenager to give to my community. While it's not obvious to others, because I get a pay-packet - I tracked my semester, my hours last semester, and I got paid for - what did I get, nine hours a week. There was not a week during the semester that I did less than 50 hours; that was the minimum.

Lyn: I do lots and lots of one-on-one with students who were absolutely struggling with an advanced course they shouldn't have been enrolled into... But we all know that there's a focus on making profit, and that comes first, and students are allowed to enrol into some courses when we know they're not prepared. We know that they haven't done courses that should be prerequisites. That puts an extra burden on us.... as a sessional you've got to figure it out alone how can I not let these 
students that are struggling fall victim to a system that's let them come into this course that they are not prepared for.

Rainee: I get up - my alarm goes off at quarter past four in the morning... because my husband works away. His alarm goes off at quarter past four so I stay in sync with him. I like to be part of his day. I get up then and the first thing I do after a cup of tea is turn on the computer and spend an hour or so replying to all of the emails from students overnight, I spend at least an hour doing emails. Then I spend time looking at the course material and...

Anna: I don't get enough work during the year to justify staying here. This year l've got two hours a week in semester one and five hours a week in semester two. That's not substantial enough pay to justify staying. Thank god my husband works. If he wasn't working this wouldn't be an option. We've had certainly moments where we've thought we can't do this, because even when my partner works, until this year his work wasn't sustaining us. We are borrowing money and going backwards. We now have a mortgage double what we had when I started my PhD...and that was in 2007.

That was on anticipation that I would get a job, and I still haven't, but to try and recoup some of that debt and make the shortfall he now works out west and I see him once a month. So it does, it affects your whole...

All: $\quad$ It affects your whole...life.

Anna: $\quad$ Life on hold.

\section{Scene 4: Delta Dawn what's that flower you have on?}

Anna: $\quad$ This is what I would do because I always wanted to ensure that because of the whole insecurity thing - that I would make an appointment to see the head of school, just to see - is there anything coming up? Am I doing the right thing? Is there anything where I could be doing better that would get me more of a permanent job or contract or whatever? I did this every year, every year.

So I would make an appointment with him and then it would get closer, and it would be like three weeks in advance because he couldn't see 
me before that. So then you get close to the appointment... and then it would be always cancelled or rescheduled. So you would get the feeling like oh yeah something else has come up. I've been kind of ... replaced. Like I wasn't important enough because it's just a waste of his time. I did this every year, every year.

Rainee: $\quad$ Well you know you're on the outside - to the point, the fulltime academic staff were having a Christmas get together where they'd brought in things for lunch and that. One of the secretaries said, 'oh come in. There's nobody here, come in and join us'. I went in and it was like freeze. It was like 'excuse me, you're a sessional', nobody said it, but it was so obvious. It was just awful. I didn't limp from the room. I just looked at them and thought...

Sharon: $\quad$ And l'd been working with this sessional for about 5 or 6 years, we taught together into the same unit. And then one year she didn't come back. And I thought, 'I wonder where Kerry is', so I asked the unit coordinator and she said, 'Oh, she died. She had breast cancer and she died.' And nobody thought to tell me.

Sharon: $\quad$ But I don't think we're deliberately left out, I think we're just forgotten about.

\section{Scene 5: There's nothing you can do about it, you can't speak up}

Lyn:

It's a bit like being in a hospital, you know. I became very aware when I was in hospital with Sarah - because you're there a lot in a cancer ward. You don't complain a lot, because you're just that little bit frightened that the staff may treat you and your child not so well. So you sort of meander through.

If anything, you're trying to please, placate and be favoured.

That's probably when I started drinking a lot. It is. But a lot of systems are like that when you're essentially powerless, aren't they?

Rainee: $\quad$ So l'd developed some really close friendships within my area and then along comes the beginning of the semester and we're not told what hours are even available until maybe two weeks before the semester starts. And when you know it's kind of like a frantic grab I suppose

Sharon: $\quad$ you are in competition with these people that you are really close to.

All: $\quad$ And I hate it 
Rainee: $\quad$ And it can cause some really bad feelings... but there's nothing you can do, you can't speak up

Sharon: I know it's hard on full time staff also - you know they can't always plan when they're going to work either and they've got other pressures... but as a fulltime academic you have a different position in the university in terms of being able to speak up. If you've got secure tenure then you can speak up for yourself and not be fearful that next semester there'll be no work

Rainee: $\quad$ That's a fear I have, I don't know if it's real but it's intimidating.

Lyn: $\quad$ That's a burden that we carry, if we speak up for our rights there's the fear that somebody's going to say 'too much trouble, stop offering that person work'.

Sharon: $\quad$ So from a... as a woman working in sessional academia, l'm very aware that this is not a power position in any way. That my job is to not cause problems for anybody. If I'm responsible, absolutely reliable, always turn up, mark properly, teach properly, don't have student complaints, I will keep getting work - and I do.

Rainee: It was brought home to me this semester - there's a colleague that has been tutoring in two of the big core subjects with me for some years. He can be quite pedantic. He got quite pedantic with the unit coordinator, who just hasn't used him this semester. So there's no recourse for him. He can't complain. He can't talk to her. He can't - she - he's just been ... blocked out. So I'm very aware of that...So you need to be really nice... you can't have an opinion that they don't like. You have to listen attentively and engage in their opinions on things, so that you're not coming in with anything that might... you can't contradict them. So much of my security is determined by the whim of the coordinator.

Lyn: $\quad$ There's this sessional that I used to be very, very close to and because of this thing that happened, it's hard to explain without going into detail, but there was a rift caused between us because of this course coordinator and it blew our relationship. Basically, if I was seen talking to her, like this other sessional who I used to be really close to... I would be sabotaging my job had I continued my relationship with her, which... I felt terrible. I've never gotten over it, and neither has she... how hurtful is that, that I would choose my job over a friendship? 
Lyn: I don't know... it's such an energy drain and it's... frightening. Often it's very frightening.

Anna: $\quad$ The middle of last year I was talking to another academic in the discipline - and I'm quite close to this person as l'd tutored with him before - and he said to me that the discipline leader told him that I was off limits... They weren't going to be giving me the teaching hours. I was off limits. Why I was off limits I don't know... so there are these silent conversations that tutors are not part of, just directly impacted by. I was shocked.

\section{Epilogue: This is the complex part of being a casual academic... we're not stupid people, we're well-educated people}

Anna: $\quad$ This is the complex part of being sessional... even though you feel, and you do know, we're not simple people... we're well-educated people; we know we're being exploited. We know we're ignored or forgotten about. Yet I've always said I feel like it's a privilege every time I walk on to the campus that I'm allowed to be here, and that's a real contradiction. That confuses me.

Sharon: There's always a feeling of insecurity, that doesn't go away but mostly the benefits, the joys of teaching outweigh that and buoy you on to keep going.

Lyn: $\quad$ So l'd be sitting up in the hospital marking papers. It was a very good thing for me to do because it was pleasurable. It sort of stretched me a bit and I could fit it in. I could still be there for my son.

And then Sarah died when she was a week off turning 12, and I did a few other things. I tried to go back to work fulltime and I joined a consulting firm and earned very good money. But I didn't really like it and I liked teaching - so came back to it.

Sharon: When I first started as sessional work in 2002 I had a different relationship with it... I was more optimistic about it.

Rainee: I had a great career path ahead of me. Over 20 years ago I was well paid. I had a full time salaried position, yeah, highly respected. I do feel that I was misled because I was - coaxed into - I was sort of courted into the idea of doing an honours degree and going on to do a masters or a $\mathrm{PhD}$ in the really true belief that there was going to be a position at the end of it, that there was a growing need for people in that area, and that's not true. I now know that wasn't true. 
Sharon: But there's always that possibility that it could happen, but it just hasn't for me - and l've been here for 13 years.

As you will identify from the stories presented above, women who shared their stories of working and living as casual academics communicated idiosyncratic experiences in fragmented yet often detailed and poetic "petits récits" (Lyotard, 1984), or short stories. The dramatic form employed in re-storying these stories thus needed to capture their personal and unique experience, as well as retain some similarity with the women's experiences. I therefore employed a polyphonic form of drama to allow several individual stories, or petits récits, to be placed alongside each other in equal value with one another. The design was employed to avoid "protagonistic" privilege, which might establish one woman/story as more relevant or important than another. Additionally, I found that a polyphonic dramatic form accommodated the presentation of "the emotional, relational, aesthetic and spiritual aspects" (Post, 1995, p. 3) of experience alongside accounts of more domestic features such as what time one of the women sets her alarm. Polyphonic dramatic structuring therefore privileges equally each of the women's stories and emotional, spiritual, physical selves.

I chose to let the women causal academics' story speak for itself and so did not add an analytical commentary to the content of the drama. As Richardson (1997) identified, researchers engaging in qualitative research expend too much energy on their exposition of data "analysis" in order to validate the captured experience and to evidence that they have drawn valid meaning, instead of allowing the stories of experience to speak for themselves. Moreover, Hendry (2010) and Richardson (1997) argue that narrative research does not need to be anchored or legitimized by analysis, interpretation or verification; it instead requires a fully present engagement with experience and research re-presentation. Similarly, Cahnmann-Taylor (2008) posited that there are more arts-based researchers writing about their research and legitimating it through a contextualisation of the criteria against which it could or should be assessed, than those providing examples of what arts-informed research actually looks like. She therefore calls for more examples of literary, visual and performing arts narrative research instead of narrative research laden with justification and explanation.

Consequently, I present above an example of dramatised research and invite each of you to take away your own reading and experience of the drama. Yet, I also invite you to consider the use of media other than traditional written discourse, and the use of a polyphonic drama in particular, to be a congruent form through which to embody the emotional, aesthetic, fragmented and poetic stories of women casual academics. Therefore, for communication to encapsulate and convey the lived experience of research participants, a "de-disciplining" and re-disciplining of academic communication (Richardson, 1997) is required in order to allow communication form to congruently align and illuminate its content. 


\section{References}

Arnot, M. \& Reay, D. (2007). A sociology of pedagogic voice: Power, inequality and pupil consultation. Discourse: Studies in the Cultural Politics of Education, (3), 311-325.

Bloomberg, L. \& Volpe, M. (2008). Completing your qualitative dissertation. Los Angeles, CA: Sage Publications.

Bruner, J. (1986), Actual minds, possible worlds. Cambridge, MA: Harvard University Press.

Bruner, J. (1990). Acts of meaning. Cambridge, MA: Harvard University Press.

Bruner, J. (1996). The culture of education. Cambridge, MA: Harvard University Press.

Cahnmann, M. (2008). Arts-based approaches in language education. In K. King \& N. Hornberger (Eds.), Research methods in language and education (pp. 243256). New York: Springer.

Coates, H., Dobson, I., Edwards, D., Friedman, T., Goedegebuure, L. \& Meek, L. (2009). The attractiveness of the Australian academic profession: A comparative analysis. Research briefing: Changing academic profession. Retrieved from: http://research.acer.edu.au/cgi/viewcontent.cgi?article=1010\&context=higher_education

Deleuze, G. (1990). The logic of sense [M. Lester \& C. Stivale, Trans.]. London, UK: The Athlone Press.

de Mello, D.M. (2007). The Language of Arts in a Narrative Inquiry Landscape. In D. J. Clandinin (Ed.), Handbook of narrative inquiry: Mapping a methodology (pp. 203-223). Thousand Oaks, CA: Sage

Etherington, K. (2004). Becoming a reflexive researcher. London, UK: Jessica Kingsley Publishers.

Evans, D., Gruba, P., \& Zobel, J. (2011). How to write a better thesis, ( ${ }^{\text {rd }}$ ed.). Carlton, VIC: Melbourne University Press.

Gould, S. (1996). The mismeasure of man. New York: W.W. Norton.

Hendry, P. M. (2010). Narrative as inquiry. The Journal of Educational Research, 10(2), 72-80. doi: 10.1080/00220670903323354. 
Lyotard, J. (1984). The postmodern condition: A report on knowledge. Minneapolis, $\mathrm{MN}$ : University of Minnesota Press.

May, R., Strachan, G., Broadbent K. \& Peetz, D. (2011).The casual approach to university teaching; Time for a re-think? In K. Krause, M. Buckridge, C. Grimmer \& S. Purbrick-lllek (Eds.), Research and development in higher education: Reshaping higher education, 34(1) 188-197.

Merleau-Ponty, M. (1962). Phenomenology of perception. London, UK: Routledge.

Richardson, L. (1997). Skirting a pleated text: De-disciplining an academic life. Qualitative Inquiry, 3(3), 295-303.

Vernon, J. (n.d.). Skinny Love. London, UK. Kobolt Music Publishing Australia Pty. Ltd.

Wake C. (2010). Towards a working definition of verbatim theatre. In P. Brown (Ed.), Verbatim: Staging memory and community (pp. 2-5). Sydney, NSW: Currency Press. 